\title{
Oriental Model: the Construction of Ethnic and Religious Harmony in Multi-Ethnic Nation
}

\author{
Wei Hong \\ School of Business, Nanjing Xiaozhuang University, Nanjing, Jiangsu, China
}

Keywords: Orient Model, religion, harmonious relationship.

\begin{abstract}
Ye Xiaowen called the long-term harmony of Chinese national religion as the "Oriental model of civilization'. But in the eastern world (East Asia, Southeast Asia), different countries have formed different ethnic and religious patterns. Islam is an important religion in Southeast Asia and has different influence in different countries. This paper tries to discuss the system construction of harmonious ethnic and religious relations in Southeast Asian countries.
\end{abstract}

\section{Introduction}

"Orient Model” was put forward by Comrade Ye Xiao Wen, former director of the state administration for religious affairs in 2006. He thinks that the situation of peace, respect and promote each other which various nationalities and religious in China formed and the long tradition and vivid practice of pluralism coexistence and harmonious cooperation in different nationalities and religious is referred to as the "Oriental Model" of civilization. He summarized it in four words without contempt or trample on each other between civilizations instead of respect and appreciate each other, without bullying the small and the weak between civilizations, instead of being tolerant to diversity. Not to distinguish the advantages and weaknesses and to compete for survival between civilizations instead of equality and mutualism. Not narcissism or blooming alone between civilizations instead of complementary and prosperity. An article written by Mr. Huang Chao discusses the practical way from the cultural dialogue to the level of religious dialogue. He thinks that the theory of the religious dialogue which be put forward in Religious Situation by Professor Duan De Zhi is not only based on the practice of oriental and western religious dialogue but also raises that the Chinese tradition build a religious dialogue mode of the oriental wisdom for cultural characteristics with gradation and unity.

The orient referred to means East Asia and southeast areas. Traditionally, the area is referred to as the "Orient Civilization'. Compared to East Asia countries, nationalities and religions of all countries in are more complex. Buddhism, Islam, Christianity (Catholicism and Christian religion), Hinduism, Sikhism as well as local and folk religion all spread widely in this area.

The population of eleven countries in Southeast Asia is 54 million. And the population of Muslim who has belief in Islam is 22 million and makes up about 40 percent of total population. The population proportion of Indonesia, Malaysia and Brunei Muslim is the largest, were 88\%,60\% and 67\%(2006).Muslim in the three countries ,along with Thailand, Philippines, Singapore and east Timor and mostly Malayan. Therefore, academia also called Muslim in the seven countries "Malay World'. And Muslim in Vietnam, Cambodia, Laos and Burma are mostly the Cham and Indian Tamils.

The influence of Islam, which is the largest religion in Southeast Asia, reflects not only the number of people, but also regional policy. In the 21st century, especially after "9.11" circles and the media began to be keen on "clash of civilization theory', which is mainly based on "the Islamic threat'. But it is generally thought that the religion of Islam in Southeast Asia is located in the edge of the Islam world. And it is mild and there aren't too many conflicts with western world. But the question on Malay's split in the south of the Philippines and Thailand, terrorist attack in Indonesia and ethnic conflicts about East Timor, Burma and other Muslims embezzling nationality of minority is serious. 
Malaysia is composed of three ethnic groups, including Malay, Chinese and Indian descent, of which India accounted for60 percent of the total population. The constitution of the Malaysia has a clear definition of the status of Islam. Islam is the state religion in Malaysia, and the head of state and the state of Sultan must also believe in Islam. Other religions and religious believers must be in "peace and tranquility" and shall not affect the status of Islam. Of course, although Islam is the state religion of Malaysia, Malaysia, in fact, is a secular state in terms of the Constitution and the social life.

From the Mahathir administration, Islamic value construction of Malaysia government tried to promote the whole society, the Islamic culture and values into the government departments in the operation, expanding the influence of Islam in national life. On the other hand, from Mahathir to Badawi, the government of Malaysia is trying to explain the interpretation of "Modern Islamic" policy concept, create a more harmonious and modern Islamic countries, and strike extremism. Malaysia has always respected and protected other religions and ethnic groups. Although Malay Islamic culture has an unshakable status, it has adopted a policy of tolerance for other ethnic groups, including Chinese, Indians, and other religions, such as the traditional Chinese belief and Christianity.

Singapore is the only country in Southeast Asia as the main body of the Chinese nation, Chinese, Malay, India is the three largest ethnic group in Singapore, accounting for the total population of $77 \%$, $14 \%$ and $8 \%$.Singapore all the nationalities, religion can long-term peace and understanding with the government of Singapore on ethnic and religious issues and develop based on this understanding of the multi-ethnic, multi religious policy guidance, checks and balances are inseparable.

Singapore constitution stipulates the basic principle of "freedom of religious belief". There is also a clear definition of "freedom": no authorization for the conduct of general laws that violate public order, public health or public morals. In 1959, Singapore established a religious commission to promote understanding and cooperation among religions, and to deepen ties with religious groups around the world. In 1990, Singapore issued the "religious harmony act", which further promoted the religious harmony and ethnic harmony in Singapore. Although Singapore is a Chinese nation, Singapore Chinese are mostly Buddhist, Taoism, Christianity and traditional folk beliefs, but the Singapore government has been committed to the establishment of a secular and religious equality of the country, adhere to the "religious neutrality", but the intervention of religious affairs.

On the whole, Singapore's Islamic policy is based on the policy of Singapore's multi religious and multi ethnic groups. On the one hand, the government to protect the Malay culture, respect the Muslim faith, on the other hand to guide the Malay community towards the "mainstream" of national life in the direction of development, to safeguard the fundamental interests of national respect for differences in the premise. It should be said that the policy of Islam in Singapore is the most successful example of several Muslim countries in Southeast Asia.

Islam is the second largest religion in Thailand, and the largest ethnic minority religious group in Thailand. According to 2000 data, Thailand's Muslim population of about 3 million 300 thousand, accounting for about $4 \%$ of the country's population. Thailand Muslims are more complex, one of the largest ethnic Malays, mainly distributed in the southern Thailand region, especially in southern Thailand four House (Pattani, Yala, Narathiwat, Satun), in addition to the people of Pakistan, Malay, Indonesia, for people and Chinese Muslims have a certain number of.

Buddhism enjoys a high status in Thailand, most of the Thai people are Buddhist, but the Thailand constitution does not give Buddhist country status, and emphasizes the principle of freedom of Religion: Religion and religious beliefs of citizens in a certain kind of religious sects and freedom, but this belief may not conflict with the citizenship. Good morality may not endanger social order and peace and the protection of citizens; countries should exercise the right to freedom, shall not be discrimination by citizens with a religion, a religious sect, a religion advocate or participate in religious activities, the damage to its deserved interests or denied their rights.

In 1932, the king issued a pardon to protect Islam, the following year and further developed for Muslim Thailand four government special law. These two laws established the principle of Thailand's management of Islam. The government of Thailand has shown full concern for Thailand's Islam. 
The spread and development of Islam in Southeast Asia and China have some similarities. First, the introduction of Islam in Southeast Asia at first was for the business basically the spread and development was in a peaceful way. Chinese Islamic was mainly introduced by Arab and Persian businessman via the road of the sea salts and the land of silk road, they mainly breed and developed through marriage and domestication .Second, the Islamic history of China and Southeast Asia is more than one thousand years and has been highly localized, which determine that the Islam in Southeast Asia and China has become an integral part of local culture, have adapted to the survival and development in the area. Third, Islam in Southeast Asia mostly is for ethnic beliefs. For example, Malays, Cham, and so on almost all believe in Islam. And in China, Islam also spread widely in the Hui, Uyghur, Kazak and so on ten minorities. Fourth, the spread of Islam in Southeast Asia is uneven. The main religion of Malaysia, Indonesia, Brunei and other countries is Islam, in the other areas, the proportion of the Islamic population is less than 10\%.In the northwest of China, the population of Muslim is large. And in other areas, it is smaller. Fifth, in some parts of southeast Asia, some of the terrorists and separatists in the name of Islam are engaged in the activities of secession and terrorist attacks, In Sinkiang, a handful of east Turkestan terrorists attempt to separate Sinkiang from China by the use of terror.

From the analysis of policy which be carried out by Southeast Asia to Islam, there are some thinking.

First, a country's national religious policy reflects the country's cultural tradition.11 countries in Southeast Asia, according to the different cultural traditions, can be divided into Malay Islamic culture, Buddhist culture, Christian culture and Chinese culture. The ethnic and religious policies of different countries also reflect the country's cultural traditions. Malaysia, Thailand, the Philippines and other countries with strong religious background in the formulation of national religious policy also embodies the "exclusive' religion. But its primary position is still in the maintenance of a certain ethnic group and the interests of the major religion and insists the difference, discrimination, exclusion and assimilation policies for a long time. When discussing the "Oriental Model", Mr. Ye particularly pointed out that in the contemporary world, where the ethnic conflicts and religions disputes exist, China and Singapore are keeping the unique landscape, which highlights the vitality and creativity of the "Oriental Model" from one side. The Chinese traditional culture-reconciliation successfully absorbed Indian Buddhism and accommodated the Islam and Christianity and finally formed the benign cultural ecology of multi-ethnic and multi-religious symbiosis in the history. With Chinese as the main body in Singapore, its ethnic and religious policies embodies the tolerance and harmony of Chinese culture, Which is also the cultural reason of Singapore's keeping the unique landscape.

Second, respect for different ethnic groups and a religious belief is the establishment of a harmonious ethnic religious relationship. One point that oriental world is different from western world is an oriental country is often not a single nation or a single religious composition. In most of the eastern countries, there will be one or a few nationalities and religions are in the majority and maintain the imbalance of this force. And the key is to respect the different nationalities and religious beliefs. As is shown in the history, the Philippines and Thailand's long Malay Muslim assimilation policy is not to establish a harmonious peaceful country, but to cause long-term conflicts and strife's. Although the policy which two countries establish in the 80s is not completely to solve disputes, but to some extent, to alleviate the ethnic and religious conflicts and create the conditions for the development of the two countries. In addition to Christianity, other religions in Singapore are based on race. Therefore, the Singapore government believes that the multi-racial led to a variety of religions. And ethnic conflicts will deepen religious barriers. However, racial harmony can promote the harmony of religion. To this end, the government of Singapore regulated that the July 21st each year is for racial harmony day, and in January 1988 passed 'Our multiracial meeting' to advocate a multi-racial, multi-cultural and multi-religious society, which is the basis of justice and stability. And it is the implementation of the integration of multi-racial policies to maintain racial harmony.

Third, we need strengthen the construction of national religious rule of law and enact effective national and religious policies. The changes of Philippines and Thailand government's policy towards 
Islam will be followed by the process of national legal system. In the period of the rule of law of national religion is not perfect, the government's relevant policies often have a strong will of a group, religion and political party. Singapore in addition to stipulating the provisions of security and rights of equality in the constitution, also issued the "Internal Security Act", the "Sedition Act", "Libel Law" and so on, to maintain social stability and religious harmony expressly .Singapore has also set up a "minority race president Council" to ensure that the government does not act against racial minorities. In order to prevent religious leaders and believers ignore Singapore radical religious pluralism maintenance society, in 1989, the government issued a "white paper" to ensure the maintenance of religious harmony, and the religion must not fight each other and not involve any religion other than that of the worldly things. In January 1991, the Singapore government published the white paper on common values, and put forward five common values. In 1994, Singapore enacted Maintenance of Religious Harmony Act, authorizing the government to restrict the freedom of those who use religion to achieve political ends and threaten religious harmony. At the same time, the Singapore government has also set up a "religious harmony Presidential Committee" to provide advice to the president on religious affairs. The committee consists of 9 members, chaired by the former Supreme judge. In 9 people, 6 people were assigned to represent Sikhism, Hinduism, Buddhism, Jesus, Islam and Catholicism. In July 20, 2003, the Singapore government issued a statement of religious harmony, encouraging Singaporeans to recite this statement within a week of annual ethnic harmony day. Except it, in the political life, language and education, community management, economic development, cultural protection, foreign policy, Singapore has developed a policy of national religious harmony.

\section{Acknowledgement}

Nanjing Xiaozhuang University project (2017).

\section{References}

[1] Introduction of religion. Beijing: People's publishing house, 2005.

[2] Xu Liping. Contemporary Islam in Southeast Asia: development and challenge. Beijing: Current Affairs press, 2008.

[3] Bi Shi. Multiple equality and harmony: an analysis of ethnic policy in Singapore. Southeast Asia South Asia studies, 2009:1.

[4] Huang Chao. Exploring the Oriental model of religious dialogue. Journal of Wuhan University (HUMANITIES SCIENCE EDITION), 2006:4.

[5] Yu Yake. Islam in Southeast Asia spread and development issues. World history, 2005:3.

[6] Wang's style of study. The causes of religious harmony in Singapore. Southeast Asia, 2005:9. 